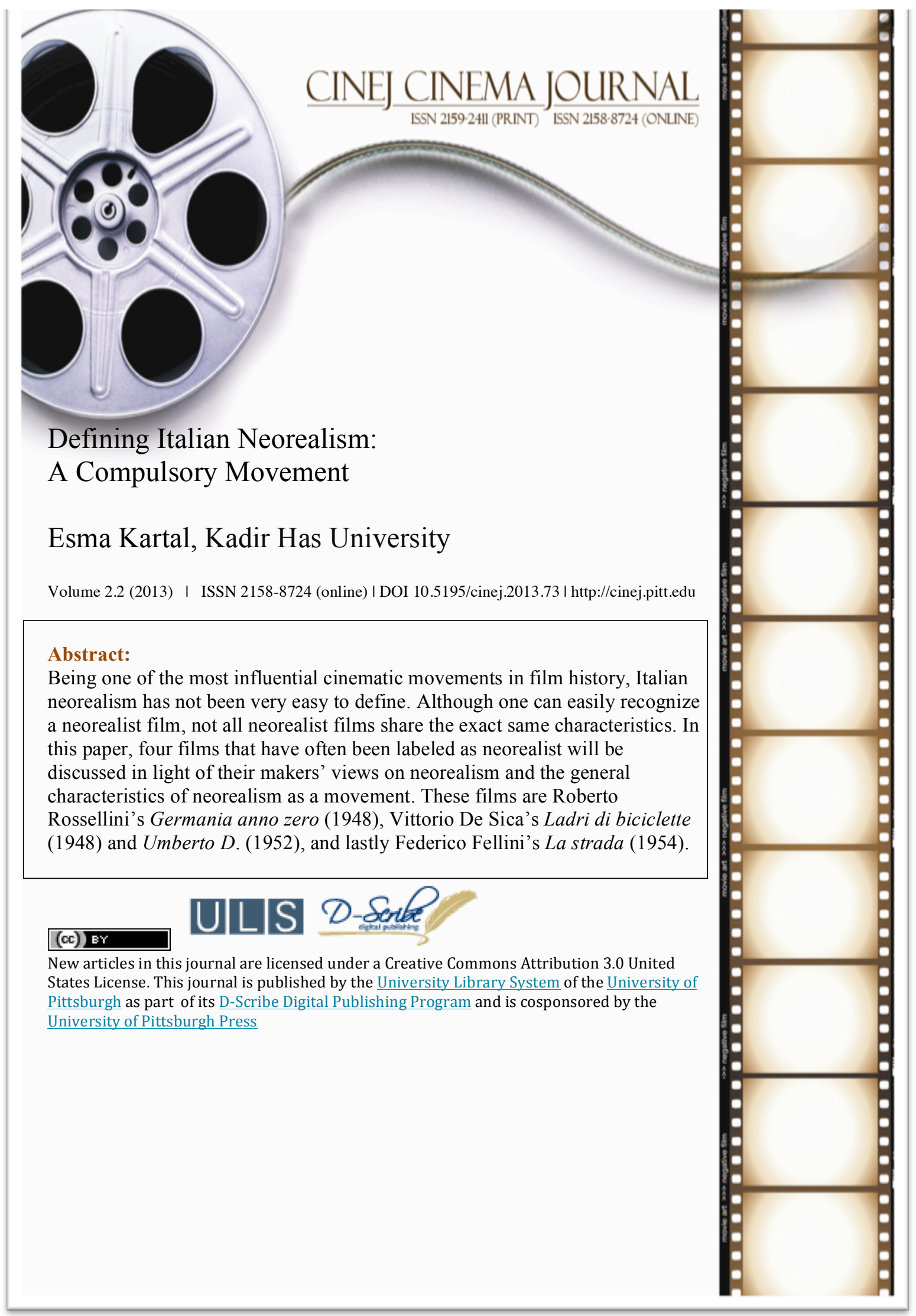




\section{Defining Italian Neorealism: A Compulsory Movement}

If one is to look at the history of cinematic movements one is bound to see many have taken place due to the artistic concerns of the people involved. For instance, such pioneers of the French New Wave as Jean-Luc Godard and François Truffaut were not content with the current situation of cinema in their own country in the 1950 s and felt that something had to be done about it. Italian neorealism of the post-war era, however, was not only an artistic reaction but it was also born out of necessity. What makes the task of defining this movement so challenging is that even though most neorealist films share a similar pattern when it comes to their themes and subject matters, they each have a distinctive way of dealing with them.

One obvious feature of almost all neorealist films is that they were shot on location instead of studios as opposed to the Hollywood films of the period. This was primarily due to the costly expenses of the Italian studios affected deeply by the war. Location shooting contributed considerably to the realistic nature of neorealist films. It had an impact on the narratives of the films, as well. In most neorealist films, locations and the spaces they form become characters themselves, and the neorealist filmmakers, knowingly or unknowingly, enable them to tell their own stories, for that matter their own histories. As Brent J. Piepergerdes points out in Re-envisioning the Nation: Film Neorealism and the Postwar Condition, in neorealist masterpieces "Space becomes open, active, and effective." (2007, p. 242). Location plays a crucial role especially in Rossellini's Germania anno zero. The film begins and ends with shots of old and worn-off buildings that depict the brutality of the war they just witnessed. When we see Edmund, the juvenile protagonist of the film, digging graves we are left questioning if decent people can really live in such places. If war can have such an effect on edifices, it is intimidating to think about its impact on individuals, specifically children.

Germania anno zero sticks out in Rossellini's filmography and in his war trilogy alike. As opposed to his other films, its protagonist is a German child. We are already familiar with the child figure in De Sica's powerful dramas. As Piepergerdes claims:

"Neorealist depictions locate children outside of the formal educational system, embroiled in the everyday and real-world struggles to survive in the postwar environment. Children are stripped of their innocence, left unprotected by the disintegration of the traditional family, often orphaned as a consequence of the war, and forced to fend for themselves. The reassurance of a sheltering domestic life is gone as boys are impelled 
to take on the role of provider and girls the role of

caregiver." (2007, p. 243-244).

For De Sica children are innocent and he uses them to have a sentimental effect on the audience. Ladri di biciclette's Bruno, for instance, has had an enormous impact on many, who have put themselves in his shoes. However, Rossellini's Edmund is not facile to identify with. Even though Rossellini shows us the other side of the line and demonstrates that the war negatively affected Germany as well as Italy, he still cannot prove Edmund to be an utterly good and innocent child. After all, he kills his own father. Nevertheless, Rossellini makes us believe that Edmund's actions are justified due to poverty brought about by the war. He achieves this in his own unique way. After spending most of the screen time on establishing a "moral and physical atmosphere", he focuses on the individual character drawing attention to Edmund's actions. As stated in Lauro Venturi's article titled "Roberto Rossellini", after the establishment of the necessary environment "Rossellini could concentrate fully on the boy and perform his feat, that of the visual exasperation that accompanies the sequence of the boy playing through the bomb-scarred streets of Berlin, his slow climb to the top of the destroyed building, and finally his suicide, the catharsis." (1949, p. 6).

Neorealist films oftentimes tend to include characters that are endeavoring to recover from the impacts of the World War II and make ends meet. In fact, economic difficulties and poverty are easily the most common themes of the movement. The actions of the characters in neorealist films are generally

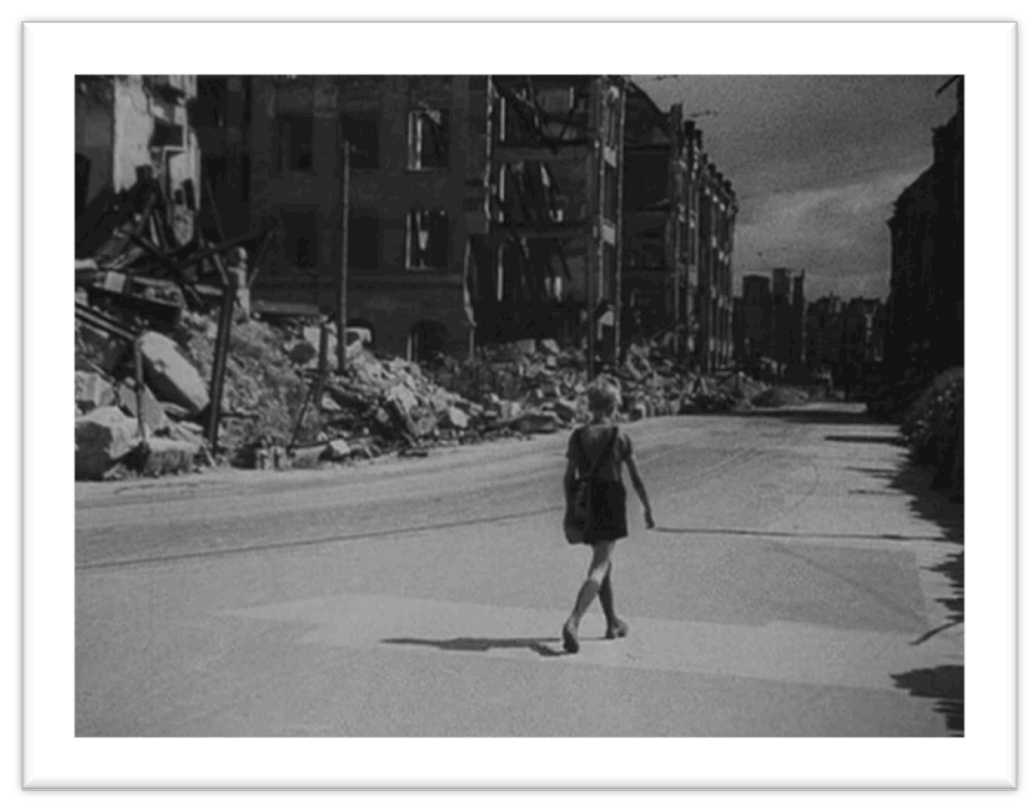

CINEJ Cinema Journal Esma KARTAL

Volume 2.2 (2013) | ISSN 2158-8724 (online) | DOI 10.5195/cinej.2013.73 I http://cinej.pitt.edu 
driven by economic conditions of the post-war era. In many neorealist examples we see individuals and/or families struggling to get by and earn their lives. The situations that they are in enforce the leading characters to do things they normally would not do. This is best exemplified by De Sica's Ladri di biciclette. After a long time of unemployment Antonio, the protagonist, starts a job which requires him to have a bicycle. Unable to afford a new bicycle, he and his wife sell their sheets to acquire some money. However, on Antonio's first day as a poster hanger, his bicycle is stolen. Despite a laborious search of

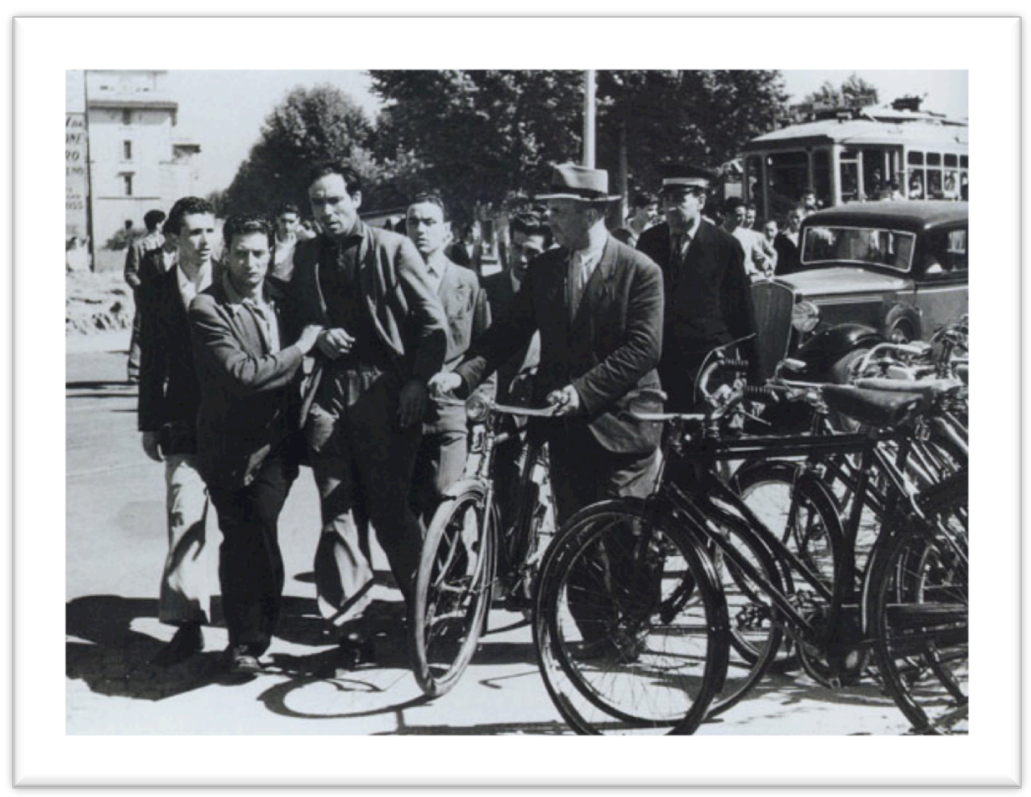

the neighborhood Antonio and Bruno cannot find the bicycle. Since Antonio cannot stand the risk of being unemployed once again, he tries to steal someone else's bicycle, hence becoming just another "bicycle thief'. In this example, as the audience we are led to believe that stealing is the only option Antonio has. This, of course, owes a lot to De Sica's mastery in creating a real character so that the audience identifies with the character depicted on screen. The success of Ladri di biciclette or any other neorealist masterpiece for that matter relies on the fact that most neorealist directors relied on life itself for subject matter. As Peter Bondanella proposes in his book Italian Cinema: From Neorealism to the Present "The controlling fiction of neorealist films, or at least the majority of them, was that they dealt with actual problems, that they employed contemporary stories, and that they focused on believable characters taken most frequently from Italian daily life." (2007, p. 34). 
Umberto D., another De Sica film, presents a protagonist similar to that of Ladri di biciclette: Umberto, an old pensioner whose only companions are his dog- Flike, and the maid of the pension he lives in- Maria. At the beginning of the film he is presented as an old man is who is having trouble finding money to pay his rent. His situation is further worsened when his snobbish landlady informs him that she will soon evict him. In a similar way to Antonio, with no other options left, Umberto practices to beg on the streets. However, as he is a respectable man he feels humiliated by this very act. But instead, he makes Flike beg. This attempt, too, fails because when Umberto comes across an old acquaintance he feels ashamed and pretends that Flike is just playing around. After all, he is a dignified man who has worked for his country for thirty years. As pointed out by Bondanella "Because Umberto is part of the middle class, his life often revolves around the protection of outward appearances - a clean shirt, proper behavior, good manners - what the Italians call a bella figura in public. As inflation and illness erode his meager pension, he is almost more afraid of losing face, of appearing poor, than of poverty itself." (2007, p. 63). In this sense, De Sica's Umberto differs hugely from other neorealist protagonists. $\mathrm{He}$ is not a worker like many other protagonists; therefore he is not accustomed to harsh living conditions. However, not all characters in neorealist films are similar, which abolishes the limitations of the movement in terms of characters. As Piepergerdes states "The presentation of poverty and unemployment that characterized the Italian postwar environment also functions as a great social equalizer in its suggestion that all citizens, regardless of class, region, and urban and rural location are confronted by the same struggle to survive." (2007, p. 245). No matter how different their backgrounds or social statuses may be neorealist characters are

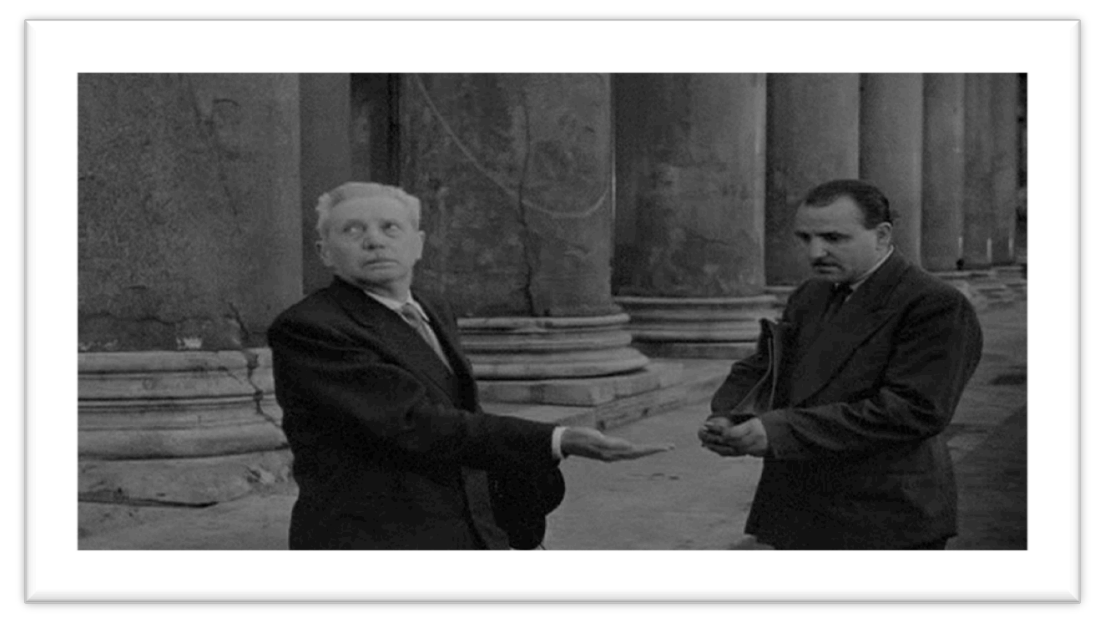

all affected negatively by the war. 
If we go back to the above-mentioned sequence in Umberto D., a well-known Italian monument forms the background for this heart-breaking moment. Vernon Young mentions this scene in "Umberto D.: Vittorio De Sica's "Super"-Naturalism" by saying "An overpowering classical column, cracked at the base, is the backdrop for this joyless act." (1956, p. 595). It is undoubtedly the Pantheon with all its glory and history, and it is not in this scene for no reason. It is one of the iconic monuments inherited by the Roman Empire that juxtaposes immensely with the present condition of Italy. The Roman Empire had a remarkable past, but with the devastating impact of the World War II this past is shaken off. In front of the Pantheon, we have Umberto, who was probably quite respected when he was still working, but now he has nothing left to do but beg for his well-being. This also exemplifies the fact that cities, buildings, monuments play a significant role in the formation of meaning in neorealist films.

In Germania anno zero Edmund is the one who takes care of the whole family. He is a child - but Rossellini treats him as an adult representative of all the German children who witnessed the World War II. He, just like Antonio and Umberto, does something the audience could never imagine: he poisons his own ailing father. However, we find ourselves identifying with him. His action is triggered by his Nazi-sympathizer teacher, Herr Enning who lectures him on social Darwinism and the survival of the fittest. Edmund, already being aware of the fact that his father detests being a burden for him and the whole family believes he is doing everyone a favor.

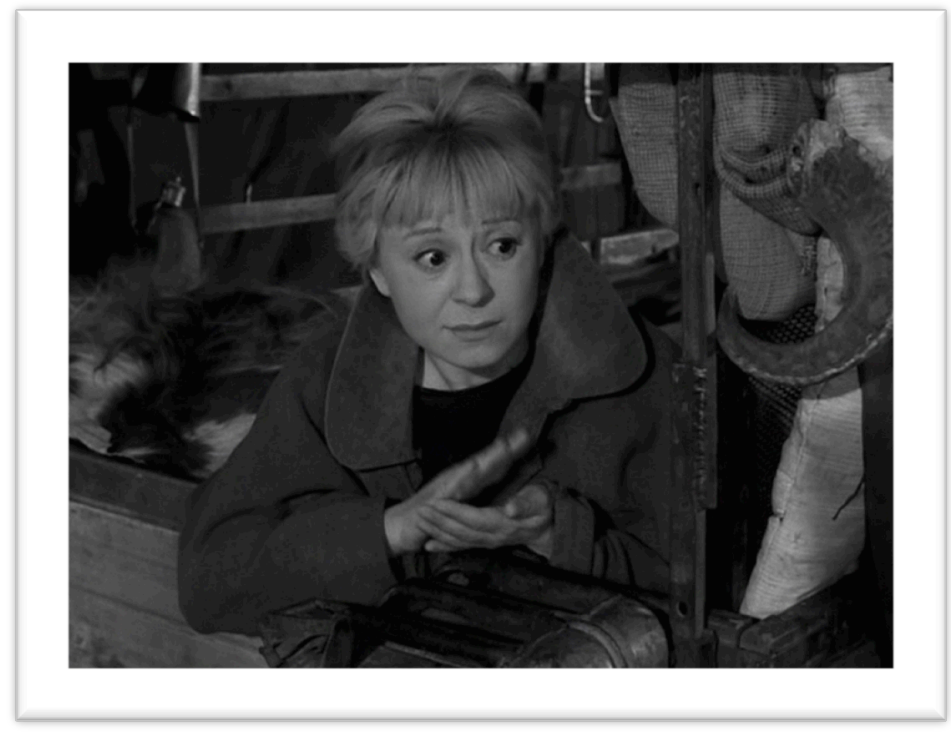


Nevertheless, he is soon to realize what he has actually done and kill himself eventually.

Most neorealist films seem to be relying on dramatic events and characters. "Thematically, the uniting factor of the master works of Neorealism... is a concern for representing the ordinary and everyday struggles of the working class in the uncertain climate of postwar reconstruction." (Piepergerdes, 2007, p. 238). As Piepergerdes highlights, as opposed to the telefoni bianchi films of the preceding years, with neorealism Italian cinema now turned its attention to ordinary people that had been overlooked for so long. The young and ambitious directors wanted to depict what they saw everyday on the streets, and hence form a different perspective on the way we look at cinema. Cesare Zavattini, the highly acclaimed screen writer and director of the era, has defined "the true function of cinema" as "not to tell fables, and to a true function we must recall it... The cinema must tell a reality as if it were a story: there must be no gap between life and what is on the screen." (Pacifici, 1956, p. 51). The economic difficulties of post-war Italy and the fascination of the neorealist directors with reality have led them to depend on non-professionals as actors. De Sica, among others, worked especially with non-professionals. As Mark Shiel writes in Italian Neorealism: Rebuilding the Cinematic City De Sica once remarked that the non-professional actor is "raw material that can be molded at will" and that "it was much easier to achieve a sense of authenticity and spontaneity with a nonprofessional than with a fully trained actor who must 'forget his profession' when working on a neorealist film." (2006, p. 56). Therefore, many important neorealist films include protagonists that have a certain "realness" attached to them.

In spite of all the misery and tragedy depicted in neorealist works they also bring polar opposite elements together. We have already established that they mostly rely on dramatic and "real" events to reach their audience. However, they also make great use of comical situations and characters. Fellini's La strada, for instance, is a good example of this. The fact that one of the secondary characters, the brute Zampano, is a traveling entertainer and that the leading character, the naïve Gelsomina is sold to him by her mother as a substitute for her now deceased sister adds up to the comical nature of the film. Gelsomina has a comical face and a clown-like appearance, which has caused her comparison to Charles Chaplin's "Little Tramp" character. In fact, she reminds us of a female version of "Little Tramp" because of her short stature, wide-eyed expressions and clumsy feet. Gelsomina and her performances with Zampano and the Fool provide the film with a comic relief, which makes the film somehow less heavy. In addition to its comical elements, La strada promises the audience more than tragedy and comedy. It unusually adopts a more existentialist discourse than many other neorealist films. This surely owes to Fellini's different approach to neorealism. In The Cinema of Federico Fellini, Bondanella quotes Fellini's description of neorealism as "looking at 
reality with an honest eye - but any kind of reality; not just social reality, but also spiritual reality, metaphysical reality, anything man has inside him." (1992, p. 70). In that sense, La strada holds a different position than other examples of neorealism. In La strada the secondary character of the Fool plays a significant role in the formation of an existentialist theme. The Fool's conversation with Gelsomina about a pebble exemplifies the existentialist nature of the film:

"The Fool: I am ignorant, but I read books. You won't

believe it, everything is useful... this pebble for

instance.

Gelsomina: Which one?

The Fool: Anyone. It is useful.

Gelsomina: What for?

The Fool: For... I don't know. If I knew I'd be the

Almighty, who knows all. When you are born and

when you die... Who knows? I don't know for what

this pebble is useful but it must be useful. For if it's

useless, everything is useless. So are the stars!"

In fact, the film never reveals the name of the Fool; we call him the Fool because Gelsomina calls him so. This might have something to do with the fact that The Fool thinks a lot and behaves in a strange manner, in a way Gelsomina has never seen. That may also be the reason she is attracted to him in the first place and what Zampano is missing. Indeed, Gelsomina repeatedly complains that Zampano never thinks about certain things.

Neorealism was a short-lived cinematic movement. It was not, however, a limited one and enabled neorealist directors to use their creativity and deal with the pressuring problems of post-war Italy. In this paper, Germania anno zero, Ladri di biciclette, Umberto D. and La strada have been discussed in terms of their subject matters, themes, and characteristics. It has been shown that not all neorealist films are similar, but rather have very distinctive qualities of their own.

\section{Bibliography}

Bondanella, P. (1992). The Cinema of Federico Fellini. Princeton: Princeton University Press.

Bondanella, P. (2004). Italian Cinema: From Neorealism to the Present. New York: Continuum.

Pacifici, S. J. (1956). Notes toward a Definition of Neorealism. Yale French Studies, 17, 44-53. 
Piepergerdes, B. J. (2007). Re-envisioning the Nation: Film Neorealism and the Postwar Italian Condition. ACME, 6 (2), 231-251.

Shiel, M. (2006). Italian Neorealism: Rebuilding the Cinematic City. London: Wallflower.

Venturi, L. (1949). Roberto Rossellini. Hollywood Quarterly, 4 (1), 1-13.

Young, V. (1956). Umberto D.: Vittorio De Sica's “Super"-Naturalism. The Hudson Review, 8 (4), 592-596.

\section{Filmography}

Amato, G. (Producer), De Sica (Director). (1948). Ladri di Biciclette/Bicycle Thieves [Motion picture]. Italy: Produzioni De Sica.

Amato, G. \& Rizzoli A. (Producers), De Sica, V. (Producer \& Director). (1952). Umberto D. [Motion picture]. Italy: Amato Film, Produzione Films Vittorio De Sica \& Rizzoli Film.

De Laurentiis D. \& Ponti C. (Producers), Fellini F. (Director). (1954). La strada [Motion picture]. Italy: Ponti-De Laurentiis Cinematografica.

Rossellini, R. (Producer \& Director). (1948). Germania anno zero/Germany Year Zero [Motion picture]. Italy: Produzione Salvo D’Angelo \& Tevere Film. 